\title{
Incidence Pattern of Rice Caseworm (Nymphula sp.)
}

\author{
Mainul Haq*, N. M. Mozaddedul Haque And A. N. M. Rezaul Karim \\ Entomology Division, Bangladesh Rice Research Institute, Gazipur, Bangladesh
}

Received 24 November 2002; received in revised form 29 September 2003; accepted 08 June 2004

\begin{abstract}
Incidence pattern of rice caseworm were studied from T. Aman (July - December) 1995 to Boro (December - May) 1998 at BRRI farm, Gazipur. Rice caseworm mostly damaged the rice plants 2 to 4 weeks after transplanting. The incidence occurred at 15th August and subsequent transplanting dates during T. Aman season and the highest leaf damage was observed in case of mid October planting. In Boro season, the incidence occurred in the late February. There were two peak incidence of caseworm in the month of August and October.
\end{abstract}

Key words: Caseworm, Nymphula sp., incidence, leaf damage.

\section{INTRODUCTION}

The rice caseworm, Nymphula depunctalis (Guenee) pyralidae : Lepidoptera) is an important insect pest of rice (Pathak \& Khan, 1994). A number of related species occur in Asia but $N$. depunctalis is most widely distributed (Reissig et al., 1995). It is an important pest of irrigated and rainfed wetland rice and occurs only in rice field with standing water. Although rice is its preferred host plant, the insect infests various other grasses as well. the insect occur regularly in low population but sporadic increases in population result in intense defoliation of plants (Dale, 1994). In Bangladesh rice caseworm is a common pest of transplanted aman rice (July - December) (Alam, 1977). The damaging stage is the larvae that live in sections of leaves cut from young rice plants and rolled into tubes called cases. The leaf cases floats to carry the larvae from one plant to another during the day and at night the larvae climb plants to cut off leaves to make new cases, or feed on severed leaves on the water surface. Rice at seedling and tillering stages are the preferred host but does not occur after maximum tillering (Pathak \& Khan, 1994).

In Bangladesh, the rice caseworm is normally occur during September to October (Hazarika, 1952; Janjua, 1957). However, Wahed (1959) reported the incidence of insect in the rice field from July to September. No systematic study on the incidence pattern of the rice caseworm throughout the year has been done in Bangladesh. Therefore, the present study has been undertaken to observe the incidence pattern and also the damage intensities of the rice caseworm.

\section{MATERIALS AND METHODS}

The study on the incidence pattern of rice caseworm throughout the year has been conducted from T. Aman (July - December) 1995 to Boro (December - May) 1998 at Bangladesh Rice Research

\footnotetext{
* Corresponding author: PSO(Entomology), BRRI, Gazipur-1701. E-mail: brrihq@bdonline.com

(C) 2006, School of Agriculture and Rural Development, Bangladesh Open University. All rights reserved.
} 
Institute (BRRI) farm, Gazipur. Thiry days old rice seedlings were transplanted in $4 \mathrm{~m} \times 4 \mathrm{~m}$ plot with $20 \mathrm{~cm} \times 20 \mathrm{~cm}$ plant spacing at an interval of 15 days. Each transplantation was replicated three times. The rice variety BR3 was planted during the tenure of the trial except in 1995 where variety BR11 was transplanted. The following transplanting dates were maintained in different years and seasons.

\begin{tabular}{|c|c|c|c|}
\hline \multirow{2}{*}{ Year } & \multicolumn{3}{|c|}{ Transplanting dates } \\
\hline & Boro (December - May) & Aus (March - July) & T.Aman (July - December) \\
\hline 1995 & --- & --- & $\begin{array}{l}1^{\text {st }} \text { August } \\
16^{\text {th }} \text { August } \\
1^{\text {st }} \text { September } \\
15^{\text {th }} \text { September } \\
1^{\text {st }} \text { October } \\
15^{\text {th }} \text { October }\end{array}$ \\
\hline 1996 & $29^{\text {th }}$ February & $\begin{array}{l}4^{\text {th }} \text { April } \\
27^{\text {th }} \text { April } \\
6^{\text {th }} \text { May }\end{array}$ & $\begin{array}{l}7^{\text {th }} \text { July } \\
20^{\text {th }} \text { July } \\
6^{\text {th }} \text { August } \\
5^{\text {th }} \text { September }\end{array}$ \\
\hline 1997 & --- & --- & $\begin{array}{l}20^{\text {th }} \text { September } \\
5^{\text {th }} \text { October } \\
20^{\text {th }} \text { October } \\
5^{\text {th }} \text { November } \\
20^{\text {th }} \text { November }\end{array}$ \\
\hline 1998 & $\begin{array}{l}5^{\text {th }} \text { December } \\
20^{\text {th }} \text { December } \\
5^{\text {th }} \text { January } \\
20^{\text {th }} \text { January } \\
5^{\text {th }} \text { February }\end{array}$ & --- & --- \\
\hline
\end{tabular}

The incidence and damage intensities of caseworm were assessed by random sampling of 20 hills from each plot of different transplanting dates at 10 - 15 days interval. In addition, number of adult casewom moth trapped in light were collected and counted every day from the light trap operated at BRRI farm, Gazipur. Standard cultural operations and continuous standing water was kept in the field to facilitate the activity of caseworm.

\section{RESULTS}

Incidence in 1995 : In T. Aman rice crop was transplanted on 1 August, 16 August, 1 September, 1 October and 15 October. Incidence and damage by caseworm was first noticed after $15^{\text {th }}$ August and leaf damage reached to about $10 \%$ at 30 days after transplanting (DAT) in $1^{\text {st }}$ August planting (Fig. 1a). Damage at $16^{\text {th }}$ August and $1^{\text {st }}$ September planting were negligible (Figs. 1b,c). However, $5 \%$ leaf damage again occurred in $15^{\text {th }}$ September planting followed by $9 \%$ in $1^{\text {st }}$ October planting (Figs.1d,c). The rice transplanted in $15^{\text {th }}$ October had the highest damage of $20 \%$ (Fig. 1f). The light trap operated at BRRI, Gazipur showed that during 1995 (Fig. 4) caseworm population was higher in the month of August and October. These populations were responsible for causing damage in September and October planting. In all the cases, caseworm preferred early stage of rice crop and the maximum damages occurred within 30 days of transplanting and were below the economic threshold level (ETL) (35\% leaf damage).

Incidence in 1996 : There were eight transplanting dates in different seasons. Among them, one in Boro, three in Aus and four in T. Aman. The incidence of caseworm was low during the year. The population and damage intensity was less than $1 \%$ in Boro planting (Fig. 2a). In Aus, the damage level reached at $1 \%$ in $4^{\text {th }}$ April planting (Fig. 2b). The insensity of damage increased to $1.5 \%$ in 
$27^{\text {th }}$ April planting and attained maximum damage of $7-8 \%$ in $6^{\text {th }}$ May planting (Figs. 2c,d). The T. Aman field transplanted in $7^{\text {th }}$ and $20^{\text {th }}$ July had less than $1 \%$ leaf damage (Figs. 2e,f). The $6^{\text {th }}$ August and $5^{\text {th }}$ September planting had slightly increased damage of about $3 \%$ and $4 \%$ respectively (Figs. $2 \mathrm{~g}, \mathrm{~h}$ ). Like previous year the damage due to the insect remained below ETL. The light trap catches (Fig. 4) indicated that due to low adult population the leaf damages also decreased during the year. The maximum number of adults caught in the light were in the month of September to November.
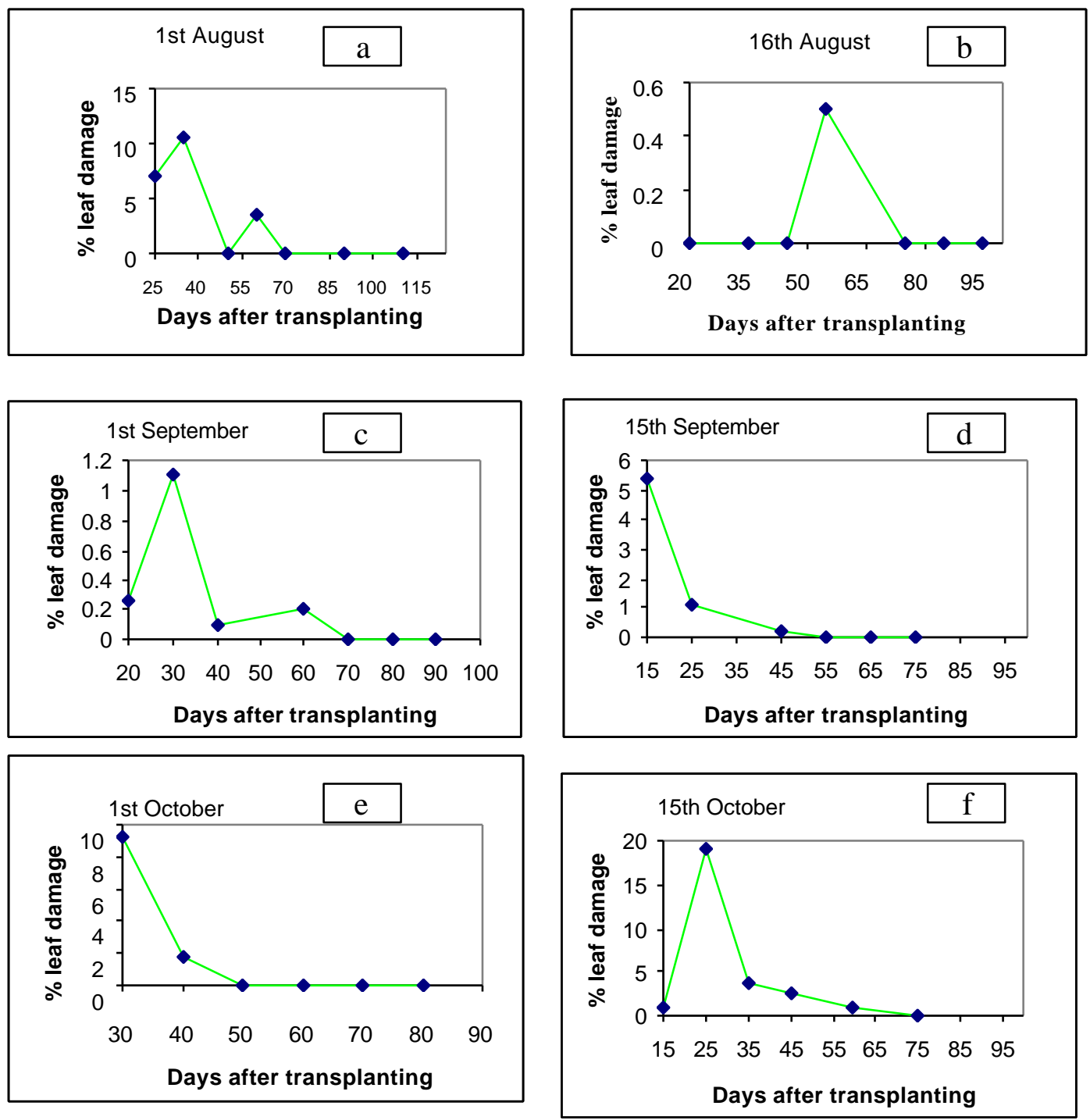

Fig. 1. Incidence and damage intensity of caseworm in rice transplanted in different time of 1995, BRRI Gazipur

Incidence in 1997-98 : Rice crop transplanted at 15 days interval starting from $20^{\text {th }}$ September 1997 and the last transplantation was made on $5^{\text {th }}$ February 1998. The damaged leaves in $1^{\text {st }}, 2^{\text {nd }}$, $3^{\text {rd }}$ and $4^{\text {th }}$ transplanting dates were $5 \%, 11 \%, 30 \%$ and $24 \%$ respectively (Fig. 3a,b,c,d). Damage 
to leaves rapidly decreased in the subsequent transplantings (Fig. 3e,f,g,h,i). However, about $4.5 \%$ leaf damage occurred in the last transplanting date $\left(5^{\text {th }}\right.$ February) (Fig. $\left.3 \mathrm{j}\right)$. The light trap incidence of caseworm during 1997 was higher during the month from September to November and the insect peaked in October. Therefore, the leaf damage were higher in $20^{\text {th }}$ October and $5^{\text {th }}$ November transplanted fields.
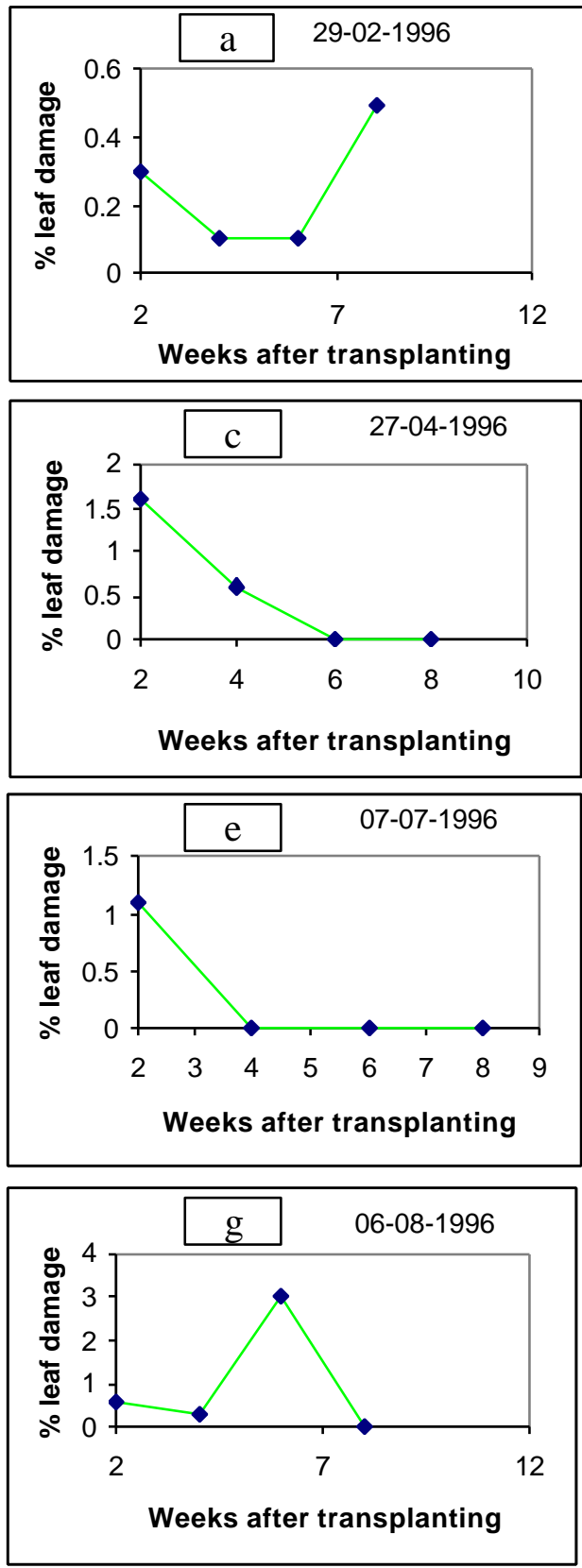
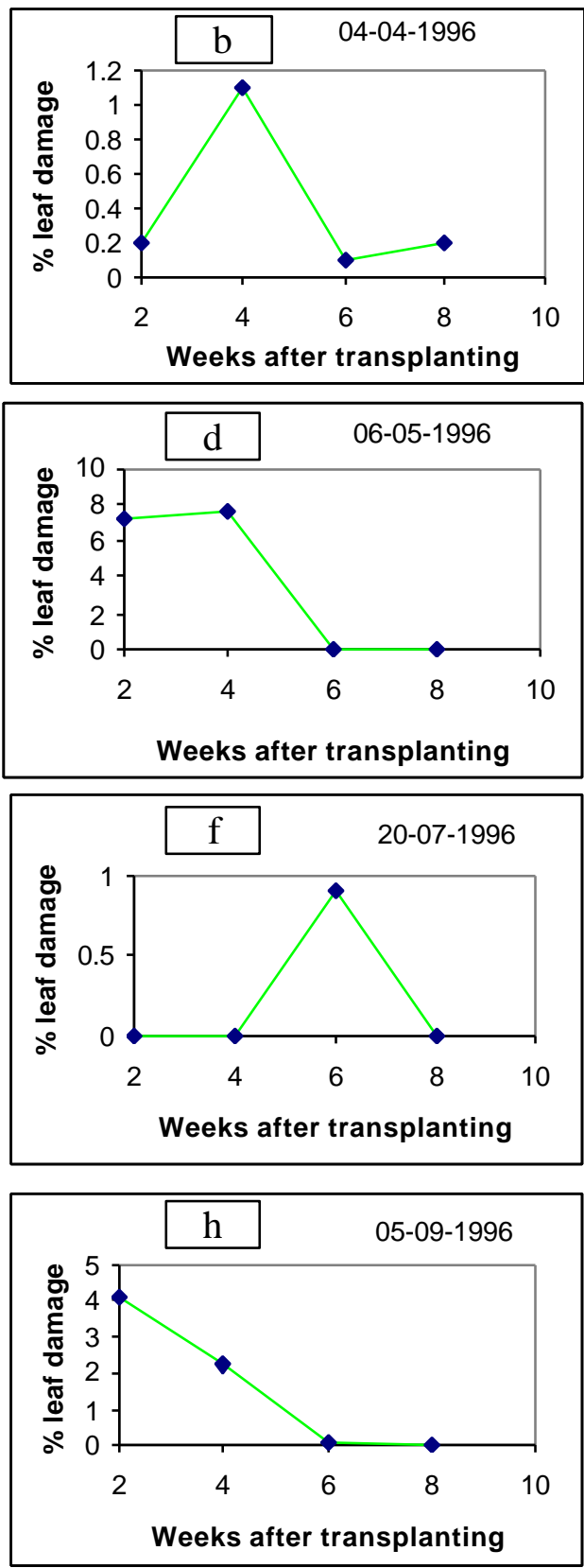

Fig. 2. Incidence and damage intensities of caseworm in transplanted rice at different intervals, BRRI, Gazipur' 1996 

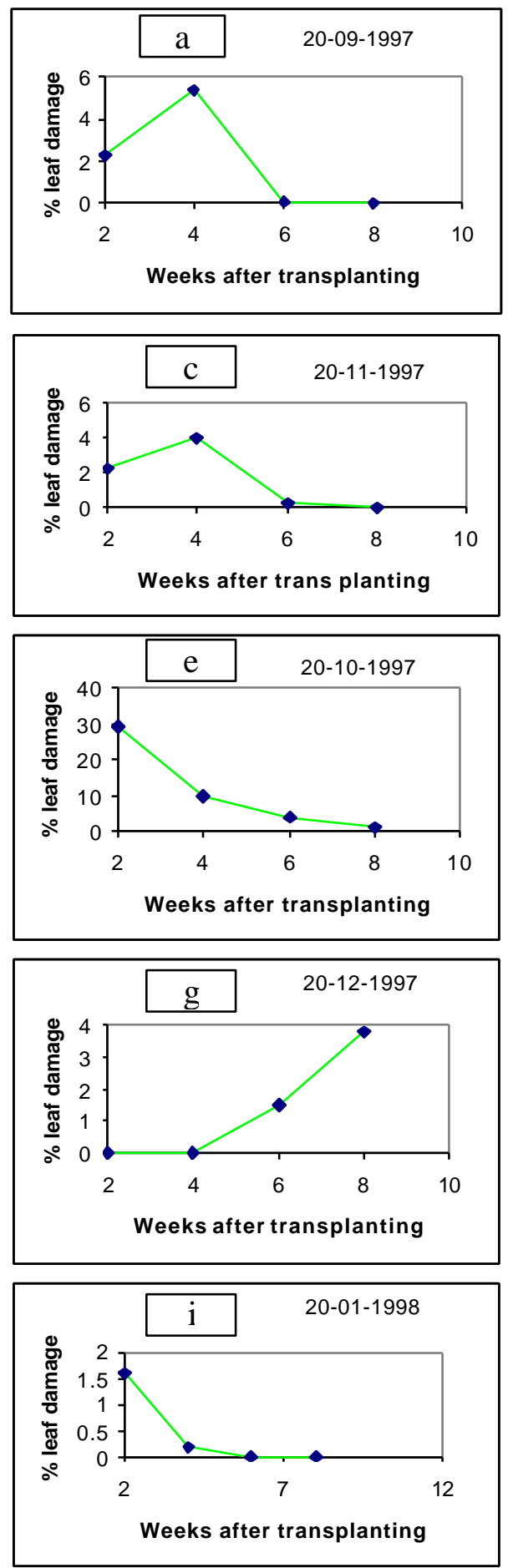
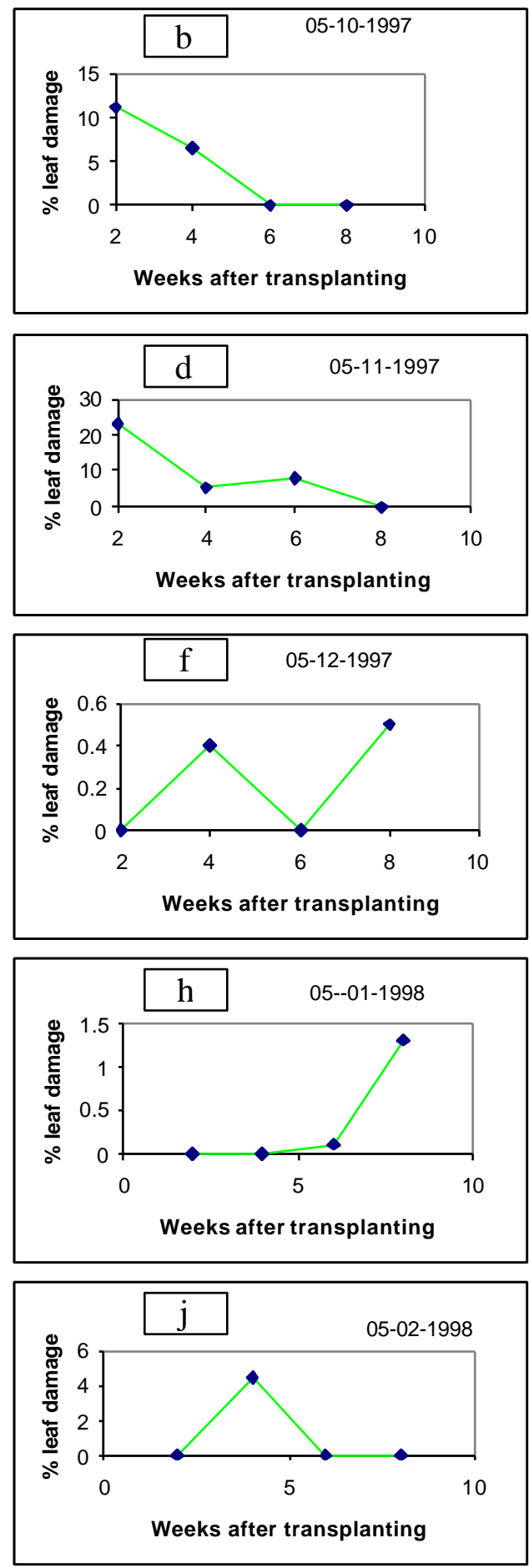

Fig. 3. Incidence and damage intensities of caseworm in transplanted rice in different time of 1997'98 BRRI Gazipur 


\section{DISCUSSION}

In the present study, the caseworm was found to cause maximum damage to rice plant within 30 DAT. The earlier workers like Pulin et al. (1998) reported that highest level of damage within 4 weeks of transplanting. Ramasubbaiah et al. (1978) also found 35-40 days as an optimum time for making maximum damage by caseworm. Litsinger et al. (1994) reported that 2-6 weeks as the most vulnerable stage for the survival of the caseworm larvae. The present study agreed with the findings of these workers.

Several years of study showed that caseworm incidence generally occurred from the months of August to November. Similarly, other authors also reported that the insect is generally found in the field from July to September ( $1 \& 12)$. The pest is usually abundant from July to November, when it infests rice plants and other grasses in the rice fields. After November, it mogrates to grassy areas (8). Fei et al. (1995) found that climatic factors like relative humidity, total rainy days and temperature were responsible for population buildup of caseworm. The peak incidence of the insect also varied depending on the climatic factors. However, two incidence peaks were recorded in the present study one in August and another in October (Fig. 4).

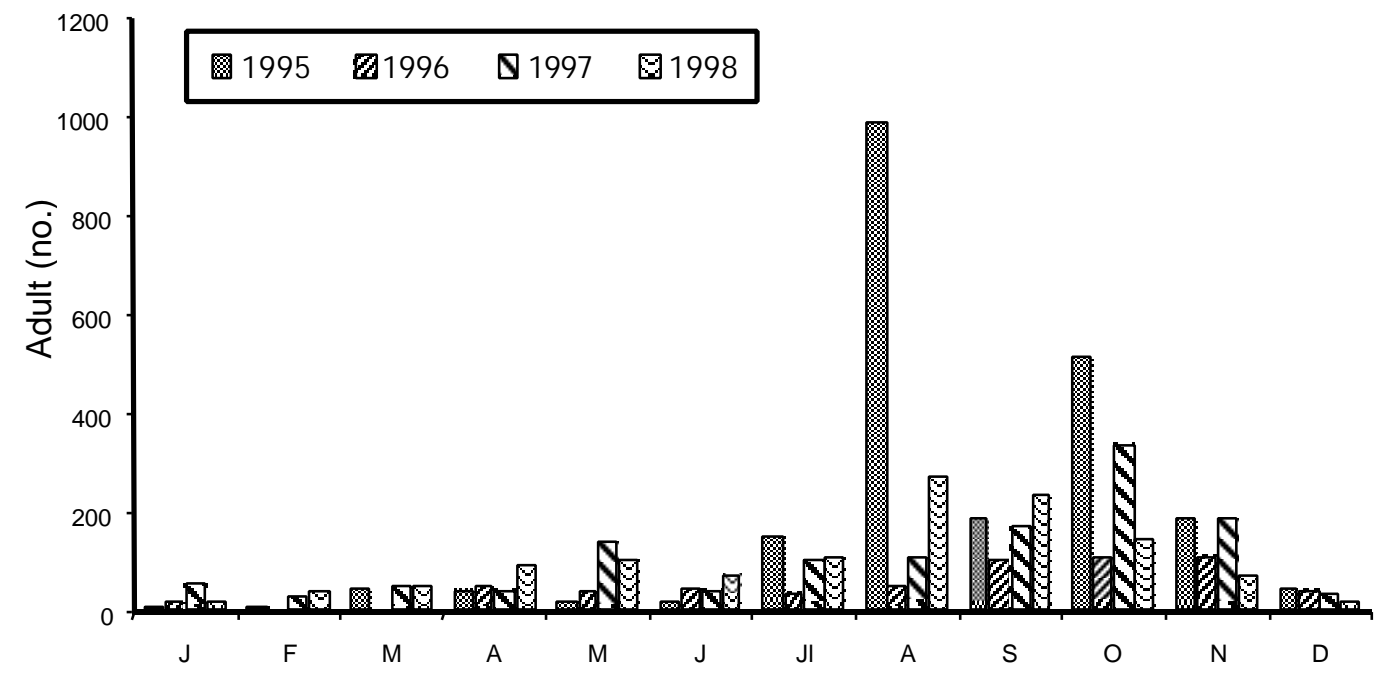

Fig. 4. Light trap catches (no.) of rice caseworm from 1995-98, BRRI, Gazipur

The rice crop planted in October suffered highest damage. Similar results were also obtained by Justo et al. (1988).

\section{CONCLUSION}

The caseworm caused damage to rice plant within 4 weeks after transplanting. The incidence pattern of caseworm generally occurred from the months of August to November. So effective management practices of caseworm should be taken at that crop stage and time of the year.

\section{LITERATURE CITED}

Alam, S. 1977. Rice caseworm. In "Literature review of insect pests and diseases of rice in Bangladesh". BRRI, Gazipur, Bangladesh. pp. 65-67.

Dale, D. 1994. Insect pest of rice plant-their bioligy and ecology, In "Biology and management of rice insect" (E. A. Heinrichs, Ed.), Wiley Eastern Limited. pp. 363-486. 


\section{Mainul Haq et al.}

Fei, H., Su, Q., Zhang, X., Fei, H., Su, Q. and Zhang, X. 1995. Effects of immigrated population and climatic factors on field population dynamics of rice caseworm. Acta-Phytophylacica-Sinica 22(3), 193-197.

Hazarika, S. H. 1952. Destructive insects of Eastern Pakistan and their control. EPG Press, Dacca- 9.

Janjua, N. A. 1957. Insect pests of paddy in Pakistan. Agric Pakistan 8(1), 5-18.

Justo, H. D. Jr., Shepard, B. M., Perez, V. A., Tiongco, E., Hibino, H. and Tsuboi, T. 1988. Pest abundance on sequentially planted crops. IRRN 13 (3), 31.

Litsinger, J. A., Bandong, J. P. and Chantaraprapha, N. 1994. Mass rearing, larval behaviour and effects of plant age on the rice caseworm, Nymphula depunctalis (Guenee) (Lepidoptera Pyralidae). Crop Protection 13(7), 494-502.

Pathak, M. D. and Khan, Z. R. 1994. Insect pests of rice. IRRI, Los Banos, Laguna, Philippines. 89pp.

Pulin, P., Khound, J. N. and Patgiri, P. 1998. Seasonal incidence of rice caseworm Nymphula depunctalis (Guen.) in Ahu and Sali rice. J Agril Sc Soc North East India 11(2), 241-243.

Ramasubbaiah, K., Rao, P. S. and Ahmed, K. 1978. A note on bionomics and control of rice caseworm. Ind J Entom 40(1), 91-92.

Reissig, W. H., Heinrichs, E. A., Litsinger, J. A., Moody, K., Fiedler, L., Mew, T. W. and Barrion, A. T. 1995. Illustrated guide to integrated pest mangement in rice in tropical Asia. IRRI, Los Banos, Philippines. 411pp.

Wahed, A. T. and Satter, A. 1959. Pests of paddy and their control measures with special reference to resistance. In "Proceedings of the first international rice breeding training center", 16-28 February, Dacca. 